\title{
THE IMPORTANCE OF ROMAN PORTRAITURE FOR HEAD-COVERINGS IN 1 CORINTHIANS

\author{
11:2-16
}

\section{David W.J. Gill}

The Corinthian correspondence presents an insight into one of the earliest Christian churches. The issues with which Paul deals have helped to mould our current views on a variety of subjects. Although the epistles speak about topics such as litigation, which is a subject familiar to us, one of the barriers to the understanding of these letters and their application for a late twentieth century church is the coming to grips with the original cultural context. Paul's teaching on the use of law courts, for example, needs to be understood against the background of litigation against the social élites of the Roman world. ${ }^{1}$ If we are to understand the background or cultural context of these letters we need to read them against the backdrop of a Roman colony, ${ }^{2}$ not a Greek city. ${ }^{3}$ Institutions, legal procedures, social customs, architecture, public images and to some extent language owed more to Rome than to the Greek world. This paper will explore the issue of head-coverings and hair-styles in 1 Corinthians 11:2-16 against the background of Roman portraiture and forms a response to C.L. Thompson's recent discussion in the Biblical Archaeologist (1989). ${ }^{4}$ It is

\footnotetext{
${ }^{1}$ B.W. Winter, 'Civil Litigation in Secular Corinth and the Church: The Forensic Background to 1 Corinthians 6', NTS (forthcoming).

${ }^{2}$ E.g. R. Oster, When men wore veils to worship: the historical context of 1 Corinthians 11:4', NTS 34 (1988) 481-505: the Corinthians were reflecting customs that were 'totally indigenous to Roman pietistic and devotional ethos' (p. 505). For the Roman colony: J. Wiseman, 'Corinth and Rome I: 228 BC-AD 267', ANRW ii 7.1 (1979) 438-548; Mary Walbank, 'Pausanias, Octavia and Temple E at Corinth', BSA 84 (1989) 361-394, with recent bibliography; D.Engels, Roman Corinth: an Alterntioe Model for the Classical City (Chicago and London, the University of Chicago 1990).

${ }^{3}$ E.g. A. Padgett, 'Paul on women in the church: the contradictions of coiffure in 1 Corinthians 11:2-16', JSNT 20 (1984) 69-86: e.g. 'part A [vv. 4-7] requires women to bow to Greek cultural norms with respect to coiffure. . ' (p. 69), 'the typical Greek fashion' (p. 70), 'Greek men during this period wore their hair short' (p. 71), "The Jews at the Corinthian church, now thoroughly Hellenized, wear their hair in the Greek style in church. . ' (p. 77).

${ }^{4}$ C.L. Thompson, 'Hairstyles, head-coverings, and St. Paul. Portraits from Roman Corinth', Biblical Archaeologist 51.2 (1989) 99-115.
} 
part of a wider project to provide the cultural background to the Corinthian correspondence by Bruce Winter and the present writer. ${ }^{5}$

\section{Men covering their heads}

Paul reminds men in the church at Corinth that any man who prays or prophesies with his head covered dishonours his head' (v. 4). He is referring to specific actions within the meeting of the church; it does not refer to every action. At Corinth several images of men with their heads covered have been found. The best known is a slightly larger than life-size statue of the emperor Augustus. ${ }^{6}$ It was found in the so-called Julian Basilica at the east end of the Roman forum. ${ }^{7}$ Augustus is shown wearing a tunic and a toga, the dress of a Roman citizen, which is drawn up over his head. The right hand, although missing, would almost certainly have held a patera, or shallow dish, for pouring libations.

This image of Augustus is one that is not confined to Corinth and there are about twenty known statues showing him as sacrificant. Most come not from Rome but from Italy and the provinces; at least five have been found in non-colonial contexts. ${ }^{8}$ A very similar statue, for example, is now in the Terme

${ }^{5}$ On which now see: B.W. Winter, 'Secular and Christian responses to Corinthian famines', TynB 40 (1989) 86-106; id., 'The Public Honouring of Christian Benefactors. Romans 13:3-4 and 1 Peter 2:14-15', JSNT 34 (1988) 87103; id., 'Theological and Ethical Responses to Religious Pluralism-1 Corinthinians 8-10'; TynB 41.2 (1990), 209-226; id., 'Civil Litigation'; D.W.J. Gill, 'Erastus the Aedile', TynB 40.2 (1989) 293-301; D.W.J .Gill and B.W. Winter, A Cultural Commentary on 1 Corinthians, in preparation.

6F.P. Johnson, Sculpture 1896-1923 (Corinth 9, Cambridge (Mass.), American School of Classical Studies at Athens/Harvard University Press, 1931) 71-72, no. 134.

${ }^{7}$ S.S. Weinberg, The Southwest Building, The Twin Basilicas, The Mosaic House (Corinth 1.5, Princeton (NJ), American School of Classical Studies at Athens 1960) 35-57, pl. 32.

${ }^{8} \mathrm{R}$. Gordon, 'The veil of power: emperors, sacrifices and benefactors', in $M$. Beard and J. North (ed.), Pagan Priests. Religion and Power in the Ancient World (London, Duckworth, 1990) 212. For distribution of the types: K. Vierneisel and P. Zanker, Die Bildnisse des Augustus (Munich, Glyptothek 1979) 58-60; S. Walker and A. Burnett, The Image of Augustus (London, British Museum Publications 1981) Maps 1-2. 
Museum in Rome. ${ }^{9}$ It is an image which was part of Augustus' propaganda which was projected to the empire. The covered head and the patera in hand indicate that the emperor is making a sacrifice in 'the manner of a Roman magistrate'. ${ }^{10}$ Although some have seen the image presenting Augustus to the viewer as the pontifex maximus, it more likely reflects his civic role; ${ }^{11}$ in other words it reflects Augustus in both a pious and a civic role at the head of the Roman world. It is an image which is also found on coins, again with his toga drawn over his head. ${ }^{12}$ Such an image is not only visual but is found in Augustus' Res Gestae where his role as pontifex maximus is emphasised. ${ }^{13}$ This adoption of a priestly role is one that is adopted by other emperors, and this is how Nero is shown in a fragmentary statue from Corinth. ${ }^{14}$ He likewise has his head partially covered by the toga.

Augustus clearly has a specific role in this statue. He is seen either about to make a sacrifice or to pray. Not everybody present at the sacrifice would have to pull their toga over their head. This feature of the so-called capite velato was the iconographical mark of a sacrificant presiding over a specifically Roman ritual' ${ }^{15}$ This imagery was commonplace at Rome. One of the best examples of Augustan religious iconography may be found on the frieze decorating the Ara Pacis Augustae at Rome, dating from 13 to $9 \mathrm{BC}$. It shows various stages in a procession, which many have seen as including members of the imperial household. Very few of the participants in the sacrifice have their toga pulled over their heads; this form of dress is confined to the priests, the two togate figures on the north side, and, perhaps significantly, Aeneas making his sacrifice. The rest of the people merely

\footnotetext{
${ }^{9} \mathrm{P}$. Zanker, The Power of Images in the Age of Augustus (Ann Arbor, University of Michigan Press, 1988) 128, fig. 104.

${ }^{10}$ Gordon 'Veil of power' 211.

${ }^{11}$ Gordon 'Veil of power' 211; cf. A. Wallace-Hadrill, 'Civilis princeps: between citizen and king', JRS 72 (1982) 32-48.

${ }^{12}$ Zanker Power of Images 127 fig. 103c.

13P.A. Brunt and J.M. Moore, Res Gestae Divi Augusti. The Achievements of the Divine Augustus (Oxford, Oxford University Press 1967) 22-23, 10.2.

${ }^{14} J o h n s o n$ Sculpture 76-77, no. 137; Weinberg, Southeast Building pl. 34.3.

${ }^{15}$ Gordon 'Veil of power' 202.
} 
wear wreaths. ${ }^{16}$ The covering of heads is not a general form of dress adopted by people attending a sacrifice; it is specific to those who are taking an active part.

Such a specific role hardly fits the context of Paul's general teaching on male head coverings. He talks of 'the head of every man (mavTòs $\alpha v \delta \rho \delta s)$ is Christ' (v. 3), and later refers to 'any man (mâs ávijp) who prays or prophesies with his head covered dishonours his head' (v. 4). Moreover his teaching does not refer to specific men within the church undertaking a very specific role. Praying and prophesying is open to every man in the church. ${ }^{17}$ As 'one of the bases of the Graeco-Roman system was to link official titles of priesthood with social status on the one hand, and with civic magistracy on the other', ${ }^{18}$ Paul may be attempting to say that if certain men adopt the form of dress suitable for a select band of people at a religious act, ${ }^{19}$ then division would occur.

Those who became priests at Corinth were normally members of the social élites. They frequently held a succession of civic offices and thus were in a very influential position within the colony. A statue base of white marble found in the shops north of the temple of Apollo would almost certainly have carried a portrait statue of one such priest. It was inscribed

To [---], priest of [----] and priest of the Tutela Augusta. The colony awarded a golden crown [-]. ${ }^{20}$

\footnotetext{
${ }^{16} \mathrm{E}$. Simon, Ara Pacis Augustae (Tübingen, Ernst Wasmuth n.d.) pls. 10 (head covered with toga and caps), 11 (wreaths), 13 (togas and caps), 24-25 (Aeneas); Zanker Power of Images 121.

${ }^{17}$ It should be noted that in the Roman world the toga could be pulled over the ears when praying so that the person would not be disturbed: Plutarch Quaest Rom 266 D.

${ }^{18}$ Gordon 'Veil of power' 201.

${ }^{19} \mathrm{Cf}$. Oster 'Historical context' 493: 'Roman apparel more often indicated the social rank of the individual'.

${ }^{20} \mathrm{~J} . \mathrm{H}$. Kent, The Inscriptions 1926-1950 (Corinth 8:3, Princeton (NJ), American School of Classical Studies at Athens 1966) 86, pl. 17, no. 193; cf. A.B. West, Latin Inscriptions 1896-1926 (Corinth 8:2, Cambridge (Mass.), American School of Classical Studies at Athens/Harvard University Press 1931) 118, no. 170, which also notes the award of a golden crown.
} 
This unknown man fulfilled an important role as priest of the imperial cult, and as a result was honoured with at least a public portrait statue and a golden crown.

Other inscriptions show that the role of priest within the colony was filled by members of the social élite. Priesthoods, although they were not not magistracies, are frequently named alongside other civic positions of authority in public inscriptions. A white marble block from the forum area lists the career of Aulus Arrius Proclus:

The Hieromnemones of the Caesarea (erected this monument) to Aulus Arrius Proclus, son of --, of the tribe Aemilia, (who was) augur, chief engineer, aedile, duovir, imperial priest of Neptune, isagogeus of the Tiberea Augustea Caesarea and agonothete of the Isthmian and Caesarean games. ${ }^{21}$

The Hieromnemones who set up this statue were Corinthian officials who supervised the sanctuary of Poseidon (=Neptune) at nearby Isthmia, and who also had a priestly function. Proclus' presidency seems to have been held in AD 39. However it is not clear how Roman in character this particular priesthood was given that the games were for the Greek world and not just the colony. A fragmentary gray marble statue base from the southeastern part of the forum and probably dating to the Augustan period also reflects how priests could be given a range of honours by the colony:

To Sextus Olius Secundus, son of Lucius, of the tribe Aemilia, who was chief engineer, priest of Jupiter Capitolinus, and who was honoured by decree of the city council with the perquisites of aedile, duovir, duovir quinquennalis, and president of the games. Sextus Olius Secundus, son of Sextus, of the tribe Aemilia, and Cornelia [Procula?], the daughter of Marcus [and wife of Secundus], (erected this monument to their father and husband) after his death.22

His final honour was to have a portrait statue of himself erected in the main public space of the colony by his family after his death. Although Secundus was clearly part of an influential family, this inscription is the only testimony to it. However his wife belonged to a very prominent family, the

${ }^{21}$ Kent Inscriptions 1926-1950 73-74, pl. 15, no. 156.

${ }^{22}$ Kent Inscriptions 1926-1950 69-70, pl. 14, no. 152. 
Cornelii, who are well known from the epigraphic record. Holding a priesthood at Corinth was an especially high honour. For example, Caius Julius Spartiaticus, a member of the Euryclid family from Sparta, was chosen to be 'the first highpriest of the Achaean League's Imperial cult' ${ }^{23}$ This is another reminder of how central the colony at Corinth was to the province of Achaea. ${ }^{24}$

The issue which Paul is dealing with here seems to be that members of the social élite within the church-the dunatoi and the eugeneis (1:26)-were adopting a form of dress during worship which drew attention to their status in society. The dress was a result of these individuals being contentious ( $\phi \lambda \lambda 6 v \in$ LKoS) (v. 16). This is a concept familiar from other parts of ancient literature, such as Plato where it is frequently linked with the love of honour $(\phi i \lambda o \tau(\mu / \alpha))^{25}$ The picture is one of rival groups, perhaps from different families, within the church who are using their dress to further their ambition to dominate and thus to be honoured by those present.

This issue is one that occurs elsewhere in the Corinthian correspondence. For example, this is probably the context for the discussion in the first chapter with people aligning themselves with different groups: "I belong to Paul," or "I belong to Apollos," or "I belong to Cephas," or "I belong to Christ"' (1:12). Individuals were pursuing litigation against each other to demonstrate their forensic skills and so gain a reputation (6:1-8). Such contentious behaviour, with its seeking after personal and family honour, threatened to cause divisions $(\sigma \chi(\sigma \mu \alpha \tau a)(1: 10)$ within the church. Thus if men were to keep their heads uncovered whilst praying and prophesying it would help to emphasise the unity of the church. If they continued to wear the toga over their heads it would indicate that there was continuing inequality in the church; the uncovered head would restate that 'the head of every man is Christ'

\footnotetext{
${ }^{23}$ A.J.S. Spawforth, 'Sparta between sympolity and municipality', in $P$. Cartledge and A.J.S. Spawforth, Hellenistic and Roman Sparta. A Tale of Two Cities (London, Routledge, 1989) 104. For the inscription: West Latin Inscriptions 1896-1926 50-53 no. 68.

${ }^{24}$ For members of the Corinthian social élite taking an interest in other cities in the Peloponnise: e.g. IG iv, 853, L. Licinnius Anteros at Methana in the Argolid. ${ }^{25}$ Republic 548 C, 545 A, 582 E.
} 
(v. 3). Indeed according to Roman custom, the uncovering of the head acknowledged the presence of other people who were worthy of honour $(\tau L \mu \gamma){ }^{26}$ To disobey Paul on this point would be to dishonour Christ and bring down shame (KaTaloXivel) on their own head, something a member of the Corinthian social élite might wish to avoid.

Although the image of the head covered with the toga conjures up the image of pagan sacrifices, this passage has probably nothing to do with shunning the worship of idols (10:14). Paul had already dealt with food offered to idols and keeping a distance from Pagan cult. ${ }^{27}$ Here he is speaking out against a form of dress which would be familiar to a Romanised or even Roman church at Corinth as placing emphasis on social status. It is unlikely to reflect Paul's desire to adopt a bareheaded form of prayer used by the Jews. ${ }^{28}$

\section{Women covering their heads}

In contrast to the bare-headed men in the church, Paul urges that 'any woman ( $\pi \alpha \sigma \alpha \quad \gamma v \nu \grave{\text { ) }}$ who prays or prophesies with her head unveiled dishonours her head-it is the same as if her head were shaven' (v. 5). Public marble portraits of women at Corinth, presumably members of wealthy and prestigious families are most frequently shown bare-headed. ${ }^{29}$ This would suggest that it was socially acceptable in a Roman colony for women to be seen bare-headed in public.

Some have taken the urge for women to wear veils as Paul ensuring that they were not mistaken for prostitutes or hetairai. Part of the reason for this view lies in the interpretation of Corinth as a 'sex-obsessed' city with prostitutes

\footnotetext{
${ }^{26}$ Plutarch Quaest Rom 266 D ('consider. . .why men cover their heads when they worship the gods. . for they uncover their heads in the presence of men more influential than they: it is not to invest these men with additional

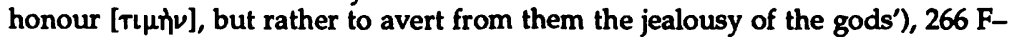
267 A ('they uncover [their heads] in the presence of good (dratois) and

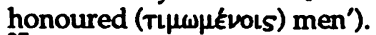

${ }^{27}$ Winter 'Responses to Religious Pluralism' 222-226.

${ }^{28}$ Thompson 'Hairstyles' 104.

${ }^{29}$ Illustrations of several may be conveniently found in Thompson 'Hairstyles'; Johnson Sculptures 86-87 nos. 160-163. An exception may be no. 164 where the woman's hair is 'enclosed in a hood which is held in place by a band around the head' (ibid. 87).
} 
freely roaming the streets. The 1000 hetairai linked to the cult of Aphrodite, and the corresponding notoriety of Corinth, belong to the hellenistic city swept away by Mummius in 146 BC. ${ }^{30}$ In contrast the Roman shrine was far more modest, and only described as a valoıv. ${ }^{31}$

Women with veils drawn over their heads are shown in the frieze of the Ara Pacis. These appear to be the Vestal Virgins who are fulfilling a religious role. However, most other women in the frieze do not seem to have their heads covered. ${ }^{32}$ The image of women capite velato like male priests is reflected in the statue of Eumachia from Pompeii. Her image was found in a shrine of the emperor in the market building and shows a woman wearing the stola over her head..$^{33}$ In her right hand she holds a patera and it is clear that the image intended to show her taking an active part in imperial cult. As P. Zanker has pointed out, the basic inconography is that used for the women of the imperial household and adopted for the families of local élites, in this case Pompeii. ${ }^{34}$ Woman priests were present at Corinth. An inscribed marble block is inscribed:

To Polyaena, daughter of Marcus, priestess of Victory. The high priest [Publius] Licinius Priscus Junventianus, [while still living, (set up this monument)] with the official sanction of the city council to (this) excellent woman..$^{35}$

This form of dress for women also appears on some coins of Tiberius which show on their reverse an image of a woman who pay be a personification of 'piety' or the 'well-being of the emperor', although some have chosen to see her as a portrait of Livia, the wife of Augustus. She is shown wearing a crown (stephane) over which is draped a veil. ${ }^{36}$ However as Paul seems to have been encouraging men not to appear capite velato,

\footnotetext{
${ }^{30}$ Strabo viii.6.20.

${ }^{31}$ Strabo viii.6.21; cf. Pausanias ii.4.7.

${ }^{32}$ Simon Ara Pacis pls. 13 (covered), 15 (covered and uncovered).

${ }^{33}$ Naples 6041: Zanker Power of Images fig. 253.

${ }^{34}$ Zanker Power of Images 322-323, 369; cf. J.H. D'Arms, 'Pompeii and Rome in the Austustan Age and beyond: the eminence of the Gens Holconia', in R.I. Curtis (ed.), Studia Pompeiana \& Classica in Honour of Wilhelmina F. Jashemski 1 (New Rochelle (NY), Aristide D. Caratzas 1988) 53.

${ }^{35}$ Kent Inscriptions 1926-1950 89, pl. 17, no. 199.

${ }^{36} \mathrm{I}$ am grateful to Kevin Butcher for drawing these coins to my attention.
} 
yet asking women to do the opposite, there might be different reasons for the two pieces of guidance.

Another context for women covering their hair is during the wedding rites. On a Proconnesian marble sarcophagus probably found at Rome, and now in the British Museum, a man and a woman are shown holding each other by their right hands (dextrarum iunctio). It should be dated to $c$. AD170-180. The woman is veiled whereas the man is bareheaded. A young man seems to attend the man, and a second woman, head covered, stands behind the couple. The meaning of the scene is indicated by the scroll in the left hand of the man, and a torch, originally held by a cupid, which may be seen by the woman's legs: it almost certainly shows a marriage scene. ${ }^{37}$ A republican funerary relief from the Via Statilia outside Rome, and now in the Capitoline Museum, shows a very similar scene. A husband and wife stand facing the viewer. The husband is shown bareheaded, whereas his wife has her head covered; as D. Strong has commented, she reflects the republican ideal of dutiful womanhood' ${ }^{38}$

This is not to say that all images of husbands and wives show the man bareheaded and the wife with her head covered. One of the best known is the portrait of a couple from a house at Pompeii. The painting, found on the back wall of a small exedra opening off the atrium probably shows the master of the house; the atrium, as we know from ancient sources, was the place to display the ancestral portraits. The husband holds a sealed papyrus roll, and the wife a double wooden folding writing-tablet. This image of the middle years of the first century $A D$, shows that women could be presented with uncovered hair alongside an image of their husband. ${ }^{39}$ This public image may be compared with the pair of bronze busts, probably husband and wife, displayed in the ala of the atrium

${ }^{37}$ S. Walker, Memorials to the Roman Dead (London, British Museum Publications 1985) 48-49, fig. 39; B.F. Cook, The Townley Marbles (London, British Museum Publications 1985) 20-21, fig. 18; S. Walker, Catalogue of Roman Sarcophagi in the British Museum (London, British Museum Publications 1990), 16-17, pl. 2, no. 4.

${ }_{38} \mathrm{D}$. Strong, Roman Art (London, Pelican 1988) 46, fig. 15.
${ }_{39} \mathrm{~J}$. Ward-Perkins and A. Claridge, Pompeii AD 79 (London, Royal Academy of Arts 1976) 20 [colour plate], no. 23. 
of the House of the Citharist at Pompeii and probably dating to the early years of the first century AD. ${ }^{40}$ They were probably members of the local Popidii family, and a second portrait of the woman, but in marble, was found elsewhere in the city; it probably formed part of a public statue. ${ }^{41}$

In chapter 11, is Paul addressing women in general or just wives? At v. 3 Paul seems to be using dinj as husband and $\gamma$ yu' as wife: 'But I want you to understand that the head of

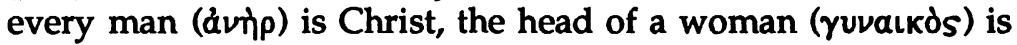

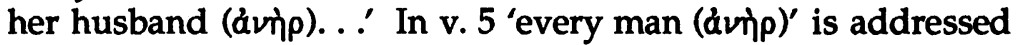
and told not to cover his head, and at v. 6 'every woman ( $\gamma v \nu \eta)^{\prime}$ ' is told to do the opposite. If women do not have their head covered, then they are seen to shame their head, that is to say their husband. The clue to this may be found at v.10 where Paul talks about the authority $(\xi \xi \circ v \sigma(\alpha \nu)$, that is to say the veil, which is worn on the woman's head..$^{42}$ The wearing of the veil said something about the wife's position in society: the lack of it at a meeting such as this would have been a poor reflection on her husband. Paul's encouragement to cover the head should be seen as an encouragement to retain some value systems of the secular Roman society.

Wives in secular Corinthian society normally wished to honour their husbands, and to be seen to have done so. An honorific statue of Sextus Olius Secundus was placed in the forum by his wife Cornelia [Procula ?] and his son (supra, p. 249). A very similar inscription occurs on a fragmentary pedestal of greyish marble from the south eastern part of the forum:

[To - who was the isagogeus of] Cornelius [Pulcher] the agonothete of the Isthmia and the [Caesarea] Sebastea, (and who was) [honoured] with the perquisites of [aedile], duovir, and [duovir quinquennalis]. [--] pina [his wife] (erected this monument to him) [after] his death. ${ }^{43}$

\footnotetext{
${ }^{40}$ Ward-Perkins and Claridge Pompeii 76 inv. 4992, no. 26.

${ }^{41}$ Ward-Perkins and Claridge Pompeii 76 inv. 120424.

${ }^{42}$ It is perhaps of note that female members of hellenistic royal families, for example Arsinoe II, wife of Ptolemy II, wore a veil on their coin portraits. This too may be a symbol of authority. See R.R.R. Smith, Hellenistic Royal Portraits (Oxford, Oxford University Press 1985), pl. 75, 5-7.

${ }^{43}$ Kent Inscriptions 1926-1950 79-80, pl. 17, no. 173.
} 
The inscription probably dates from the reign of Domitian. Another inscription on a greyish marble base, and found in the South Stoa adjacent to the forum, draws attention to four generations of one family which suggests that it was prominent in the colony:

To Gnaeus Publicius Rusticus, son of Marcus, grandson of Marcus, great-grandson of Marcus, of the tribe Aemilia, who was honoured with the perquisites of duovir, duovir quinquennalis, and agonothete; and to [- his wife]. Marcus Publicius [son of Gnaeus and] Babbia his wife (erected this monument) to their parents [after their death?] with the consent of the city council. ${ }^{44}$

The inscription reminds us of the importance of the family, and Paul may well have been appealing to women not to dress in a way that would bring dishonour to their husbands and families in what was a status conscious colony.

Women could wear their hair long in public at time of mourning but Paul is here talking specifically about a woman who takes part in the service. A woman with long uncovered hair is seen in the wall-paintings of the Villa of the Mysteries just outside Pompeii. 45 One partially naked woman, resting her head on the lap of another is being struck by a further winged female, part of a possible ritual flagellation. Although the interpretation of the scene is the subject of considerable discussion, the flagellation seems to be part of an initiation ceremony, perhaps linked to the cult of Dionysos. Elsewhere Livy refers to women having their hair unbound when attending the cult of Dionysos at Rome. ${ }^{46}$ Dionysiac religion allowed women to take part in a cult in a way normally denied them in male dominated urban society. There are numerous contrasts with the usual world of cult: the ceremonies take place in the mountains, not in the sanctuary, the animals are wild not domesticated, the sacrificial beasts are torn apart and eaten raw instead of being slain with a knife and cooked. It is

\footnotetext{
${ }^{44}$ Kent Inscriptions 1926-1950 81, pl. 17, no. 176.

${ }^{45}$ Ward-Perkins and Claridge Pompeii 84-85 [colour plate], no. 204; A. Maiuri, La Villa dei Misteri (Roma, La Libreria dello Stato 1931), pl. R. For the statue of a woman with her head covered for the same villa: ibid. 225-231, figs. 9398.

${ }^{46} x x x i x .13 .12$.
} 
perhaps this type of mystery religion which attempted to go outside the norms of society which Paul wanted to avoid. Female members of the church could not be seen to be taking part in some mystery religion which in some ways undermined society.

Paul urges that if a woman will not veil herself, then she should cut off her hair; but if it is disgraceful for a woman to be shorn or shaven, let her wear a veil' (v. 6). The wearing of shorn or shaven hair by women was a mark of humility or humbling. Plutarch tells us that in Greece, whenever any misfortune comes, the women cut off their hair and the men let it grow. . ${ }^{\prime 47}$ Dio Chrysostom talks about the shaving of women's heads as a sign of humiliation in his discussion of Demonassa of Cyprus who gave the people of that island three laws. ${ }^{48}$ The first states 'a woman guilty of adultery shall have

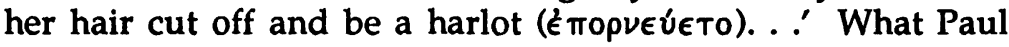
may be saying is that if women in the church will not wear a veil, then they will be seen as dishonouring their husbands which might affect their place in society. If the wife insists on being unveiled then she might as well wear a sign of humiliation by having her hair cut. If she does not wish to bring such shame (al $\sigma \chi \rho \circ \nu)$ to her husband, herself and her family then she should be veiled.

\section{Paul's appeal to nature}

From the issue of the veil and exousia, Paul turns to the issue of the length of hair. His appeal is not to scripture but to nature: Does not nature ( $\phi \dot{v} \sigma \iota_{s}$ ) itself teach you that for a man to wear

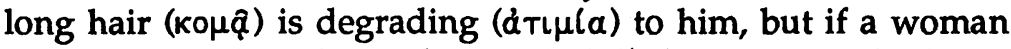

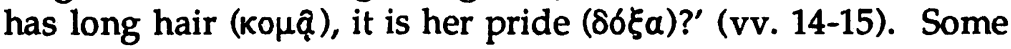
have seen Paul's argument as unworthy of 'a Roman citizen with claims to literacy in Greek' as literary sources, visual images and even Jewish heroes bear testimony to men wearing long hair. ${ }^{49}$ Paul however is probably making a distinction between the sexes. He has just underlined the wife's role acknowledging the authority of the husband through the

${ }^{47}$ Quaest Rom 267 B.

${ }^{48}$ Discourses lxiv.2-3.

${ }^{49}$ Thompson 'Hairstyles' 104. 
wearing of a veil in the church. He now turns to other issues where distinctions should not be blurred.

It should be remembered that Paul is addressing a church which included members of the social élite at Corinth. It is thus immaterial that farmers or foreigners wore their hair long ${ }^{50}$ if the custom in a Roman colony was for the men to wear their hair short and for women to wear their hair long. Although it has been stressed that Paul would have been able to see statues of 'long-haired men', 51 it should be remembered that many of these statues represent not men but gods. In particular Apollo and Dionysos were shown with locks falling onto their shoulders. Paul is rather emphasising the need for men and women to fulfil their current roles in society. The church was to permeate society not to rebel against it.

It is within these social constraints that Paul introduces the concept of $\dot{\alpha} \tau \mu l \alpha$ or dishonour (v. 14). In a colony where honours abounded, Paul is encouraging the men not to adopt an appearance which could only bring dishonour. The term is frequently contrasted with $\delta 6 \xi \alpha$ in 2 Corinthians 6:6, 1 Corinthians $15: 43$ and 4:10. In the latter reference, Paul specifically places members of the Corinthian church as

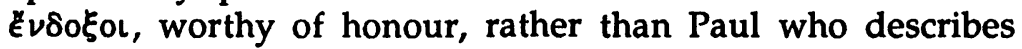
himself as \&turos. If Paul was using фbots in the Stoic sense, in which 'nature is the origin and guarantor of culture', ${ }^{52}$ his appeal is to the men's own Roman cultural background.

It is in this context that the wearing of long hair by women is described by Paul as their glory $(\$ 6 \xi \alpha)$. As members of the social élite in the colony, Paul was urging them to retain the dress of their group. The danger would be that after conversion they could adopt different dress and distance themselves from the society to which they were to be witnesses. The wearing of long hair is seen in portraits of female members of Corinthian society. A marble portrait from the early years of the colony shows a woman whose long hair has been 'twisted into a roll at the top of the head, comes

\footnotetext{
${ }^{50} \mathrm{Cf}$. Dio Chrysostom xxxv.

${ }^{51}$ Thompson 'Hairstyles' 104.

${ }^{52}$ D. Jobling, "And have dominion. . ." The interpretation of Genesis 1, 28 in Philo Judaeus', JSI 8.1 (1977) 79. I am grateful to Dr Bruce Winter for this reference.
} 
forward to the forehead, and then doubles back, forming a raised, looped ridge'. ${ }^{53}$ Later portraits of the second century AD show that the tradition of long hair continued, although the hair was braided. ${ }^{54}$ Indeed it is this long hair that is seen as a head covering which is worn instead of a veil (v.15: $8 \mathrm{TL}$ in

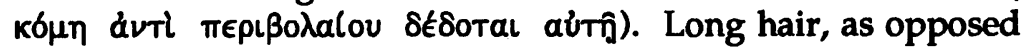
to a shaven head, was a symbol in Roman society of a wife's relationship to her husband. ${ }^{55}$

\section{Roman portraits for a Roman colony}

Public images of individuals at Corinth may also inform us about aspects of the city other than hairstyles. One of the recent issues has been a discussion over how Roman the colony was. ${ }^{56}$ First it should be remembered that the colony was in effect a new foundation, as the city had lain desolate for over a century. Although the archaic temple overlooking the forum is essentially Greek (there were some Roman modifications to the internal structure), the public buildings and temples are essentially Italian; in layout parts of the city even recall the Forum of Augustus at Rome. This may be contrasted with Athens, which remained a Greek city, where Augustus moved a Pericleian fifth century $B C$ temple from the Attic countryside to house the cult of Gaius. This was placed in the middle of the main public space in the heart of the city, the agora. Moreover the monumental tomb of Lucius Castricius Regulus, duovir quinquennalis under Tiberius, overlooking the harbour at Kenchreai, the eastern port of Corinth, is very Roman in design and incorporated the Roman version of the Ionic column.57 At Corinth public inscriptions are predominantly in Latin rather than Greek, ${ }^{58}$ this is especially noticeable when identical texts

\footnotetext{
${ }^{53}$ Thompson 'Hairstyles' 107.

${ }^{54} \mathrm{Cf}$. Thompson 'Hairstyles' 110.

${ }^{55}$ Thompson 'Hairstyles' 112 takes this to mean that Paul 'suggrested that women's long hair be a "wrapping". . that is, fastened up, as contrasted to being allowed to flow unimpeded around the shoulders'.

${ }^{56} \mathrm{G}$. Theissen, The Social Setting of Pauline Christianity. Essays on Corinth (Edinburgh, T. \& T. Clarke 1982), 79, 112 n. 20.

${ }^{57}$ W.W. Cummer, 'A Roman tomb at Corinthian Kenchreai', Hesperia 40 (1971) 205-231.

${ }^{58}$ Kent Inscriptions 1926-1950 18-19. For the later change back to Greek: J.H.

Oliver, 'Panachaeans and Panhellenes', Hesperia 47 (1978) 191.
} 
are found elsewhere in Greece. For example, C. Julius Spartiaticus, a member of an important family from Sparta, is known from a Latin inscription which formed part of a base at Corinth, ${ }^{59}$ as well as Greek inscriptions at Athens, ${ }^{60}$ Epidauros ${ }^{61}$ and Sparta. ${ }^{62}$ However graffiti on pottery show that Greek was used, ${ }^{63}$ and it is perhaps of note that Paul wrote to the Corinthian church in Greek rather than Latin.

The life-size statue of Augustus as a priest has already been discussed in connection with the image of men wearing head-coverings. This image was one entirely suitable for a Roman colony where cult was in essence Roman rather than Greek. The image of the Roman magistrate as a priest might be an inappropriate one for a Greek city, but an appropriate one for a Roman colony. It was found in the Julian Basilica by the forum, a building in which were also found two virtually naked youths. ${ }^{64}$ Although their bodies are based on the famous fifth century BC Canon of the sculptor Polykleitos, the Doryphoros ('spear-carrier'), the heads are clearly portraits of two JulioClaudian princes. Several have tried to identify them as the brothers Gaius (20 BC-AD 4) and Lucius (17 BC-AD 2) who were to have succeeded Augustus, and it has been suggested that they formed a group in a building of the early colony. ${ }^{65}$ A third headless statue was found in the South Basilica, a twin to the Julian Basilica, and it may also have been part of an original sculptural group. ${ }^{66}$ The successors to Augustus are not however presented like the emperor in Roman guise. They are virtually naked, which is unusual for portrait statues of Romans. It seems that a Greek statue type was adopted to become the vehicle for presenting part of the imperial image. They were Roman portraits of the Roman imperial family presented in Greek guise. This might suggest that the audience were familiar

\footnotetext{
${ }^{59}$ West Latin Inscriptions 1896-1926, no. 68.

${ }^{60}$ IG iii, 805.

${ }^{61}$ IG iv, 1469.

${ }^{62}$ IG v.1, 463.

${ }^{63} \mathrm{~J}$. W. Hayes, 'Roman pottery from the South Stoa at Corinth', Hesperia 42 (1973) pl. 95.

64 Johnson Sculpture 72-76, nos. 135-136; Weinberg Southeast Building pls. 33-34.

${ }^{65}$ Weinberg Southeast Building 53-54.

${ }^{66}$ Weinberg Southeast Building 74, pl. 46.2.
} 
with Greek styles of sculpture and that this was a concession to their cultural background.

\section{Conclusion}

The issue which is discussed in these verses seems to be a continuation of the problems faced in the early chapters of the epistle. ${ }^{67}$ It seems to reflect the jostling for power and authority amongst the leading families within the church at Corinth after Paul's departure. It reflects the love of ambition usually met within an urban community of the Roman world such as a colony. It is this rivalry which could lead to division which Paul is trying to counteract. It may also be a reflection that as Corinth was 'the centre of Romanitas in Greece', ${ }^{68}$ members of social élite were wanting to establish a Roman element into their worship. Paul recognised that such people should not be allowed to dominate the church and to exert a wrong influence. Although for men Paul counteracts their desire to apply secular models into their ekklesia, in the case of women Paul restates that they should continue to place a high value on marriage and should not flout social conventions in the church meeting purely for the sake of being contentious. ${ }^{69}$

${ }^{67}$ These will be discussed in Andrew Clarke's forthcoming University of Cambridge PhD thesis on secular and Christian leadership in Corinth.

${ }^{68}$ Spawforth 'Sparta' 104.

${ }^{69}$ This paper was first read to the Tyndale Fellowship Biblical Archaeology Study Group in July, 1990, and I am grateful to Bruce Winter and Andrew Clarke for their comments on an earlier draft. The Travelling Expenses Fund of the University of Cambridge contributed towards a study of these portraits in Corinth (1990) where Dr Charles K. Williams II and Dr Nancy Bookidis of the American Excavations offered their assistance. 